\title{
IS BITCOIN BECOMING AN ALTERNATIVE INVESTMENT OPTION FOR TURKEY? A COMPARATIVE INVESTIGATION THROUGH THE NON-LINEAR TIME SERIES ANALYSIS
}

\author{
DOI: 10.17261/Pressacademia.2018.1009
}

RJBM- V.5-ISS.4-2018(3)-p.250-261

\section{Mustafa Cikrikci ${ }^{1}$, Mustafa Ozyesil ${ }^{2}$}

${ }^{1}$ Istanbul Aydin University, School of Economics and Administrative Sciences, Accounting and Finance, Istanbul, Turkey mustafacikrikci@aydin.edu.tr, ORCID: 0000-0002-2805-6079

${ }^{2}$ Istanbul Aydin University, Anadolubil Vocational School, Business Management (English), Istanbul, Turkey mozyesil@aydin.edu.tr, ORCID: 0000-0002-4442-7087

To cite this document

Cikrikci, M., Ozyesil, M. (2018). Is bitcoin becoming an alternative investment option for Turkey? a comparative investigation through the non-linear time series analysis. Research Journal of Business and Management (RJBM), V.5(4), p.250-261.

Permemant link to this document: http://doi.org/10.17261/Pressacademia.2018.1009

Copyright: Published by PressAcademia and limited licenced re-use rights only.

\section{ABSTRACT}

Purpose - The main purpose of this study in determine whether Bitcoin is becoming an alternative investment option compared to other financial instruments in Turkey. To perform analysis for this purpose, we created sample includes Bitcoin, Bist 100 National Index, Bond, Euro and Gold. We calculated daily returns in terms of \% for each type of instrument for the period range from 02.02.2012 to 17.12.2018. Methodology - In the study, we tested the stationarity of the series and the causality relationships between the series through the nonlinear unit root and causality tests. Stationarity of the series and causality relations between them are determined with the help of charts. Both in unit root test and in causality test, firstly we obtained test statistics and normalized them by using critical values then transferred them to the charts. In order to decide about when test statistics is higher than critical values null hypothesis is rejected.

Findings- Bitcoin, Usd, Gold and Bond are found non-stationary for the whole period. We find out that returns of Euro is more stable than Usd. Bitcoin has been fluctuating during all period except for first months of 2013 while Gold's returns are intensively volatile when politic and economic risks are increasing. This show investors in Turkey still consider Gold as safe port for their investments. Usd currency is volatile for all period because of its increasing demand all over the world. In causality test we observed that there is a causality relation from Bitcoin's returns to Bist 100 returns. This result shows that Bitcoin is becoming an alternative (substitute) investment tool for domestic and foreign investors compared to Borsa Istanbul. There is more causality relation between Bitcoin and Gold than Bitcoin and Bist 100.

Conclusion- Based on the findings of this analysis, , it may be accepted that Bitcoin has been becoming an alternative investment/savings tool for the Turkey case. Regulatory institutions should create a required legal framework for the Bitcoin because Bitcoin has a great potential to prevent of tax evasion, the terminate the informal economy and eliminate intermediation costs.

Keywords: Bitcoin, Non- Linear Unit Root Test, Non- Linear Causality Test, Varying Time Series, Borsa Istanbul. JEL Codes: C22, G10, G11

\section{INTRODUCTION}

Money has been used as a exchange tool in the economy for centuries. Money as an economic unit of measurement, which is considered equal to the value of the related goods and services in process of transfer from seller to buyer, has the most fundamental impact on the formation and spread of trading activities. In the absence of this unit of measurement, which is used by all for the purpose of commercial operations, goods and services were being transferred from the seller to the buyer sides through the swap transaction called barter and people would have to give objects with a higher value in exchange to these mentioned goods and services, then common economic exchange values that everyone could use were found (Ates, 2016:352). Nowadays, the enormous developments in information technologies have affected the financial system and the money has started to be produced under the name of Crypto Currency by taking a new form (Hepkorucu and Genç, 2017 : 48).

Crypto currency is defined as the digital value that enables secure transaction processing through encryption and the creation of additional virtual Money (Çarkacıoğlu, 2016:8). Cryptology has been used in the process of ensuring the 
reliability for money supply and financial transactions and its first theoretical framework was established in 1998 by Wei Dai (Gültekin and Bulut, 2016:83). These currencies are available as virtual and digital.

Among the crypto Money types, nowadays Bitcoin is one of the most popular topics in finance environment. Bitcoin is an encrypted and universal electronic money designed in 2008 by people or individuals with the nickname Satoshi Nakamoto (Atik et al. 2015:249). Particularly due to abnormal price movements, Bitcoin is defined as a risky instrument according to some analysts, while it is defined as a profitable investment tool by other analysts. Unlike conventional paper currency circulation, bitcoin can be defined as the virtual currency produced in the digital platform.

The main features that differentiate the Bitcoin virtual currency from the classic currency concept are (Atik et al. 2015:249)

- $\quad$ There is no supply center. In other words, control is not carried out by the person, company or countries.

- It is traded on a peer-to-peer network. This network can make its own network configuration without the server.

- Crypto technique was used in its production and circulation.

In addition, the upper limits for the amount of bitcoin in circulation are defined and the total amount of bitcoin is limited to 21 Million (Hepkorucu and Genç, 2017 : 48).

\section{DATA AND METHODOLOGY}

In this study, interactions among the crypto-currency (Bitcoin), Borsa Istanbul Stock Exchange (BIST), foreign exchange currencies, bonds and gold were analyzed using the data belong the 02.02.2012-17.12.2018 period. Data and types can be seen in Table 1.

Table 1: Data Types Used In the Study

\begin{tabular}{ll}
\hline INSTRUMENT & TYPE \\
\hline Bitcoin (BITCOIN) & Cryptocurrency \\
\hline BIST 100 national index & Equity (Borsa Istanbul) \\
\hline USD and EUR & Foreign Currencies \\
\hline 24 Gram Gold & Gold \\
\hline
\end{tabular}

10 years term government bond Bond

All variables in the analysis are included in the calculation based on their daily returns. The data were obtained from the tradingeconomics.com. In the selection of the analysis period, the broadest time range (beginning from the first date of bitcoin to the latest date for this analysis) was taken into consideration. Finally, the study was carried out using 1705 daily data.

In this study, the stability of the series was examined through the KSS time-varying nonlinear unit root test developed by Kapetanios, Shin and Snell (2003). The existence of causality relationships between the series was analyzed via the LBGC time-varying nonlinear causality test developed by Li, Balcılar, Gupta and Chang (2016).

\subsection{Unit Root Test}

Linear unit root tests acknowledge that the series is stationary over time and give a single result for the whole period. However, series may be stationary in some parts of the time range, while in others it may not be stationary. In order to reveal this, in this study, the stationarity of the series was examined by the time-varying and non-linear unit root test (KSS) developed by Kapetanios, Shin and Snell (2003). The abbreviation was created using the initials letters of the authors' 
surname. This approached has been already used in the literature such as Yılancı (2009), Ağazade (2014); Destek and Okumuş (2016).

In this test, it is also taken into account that the stationary of the series may vary over time and they may not be linear. The KSS test is based on a single-variable, Smooth Transition, one-degree autoregressive model STAR(1)) :

$$
\begin{aligned}
& y_{t}=\beta y_{t-1}+\gamma y_{t-1} \Theta\left(\theta ; y_{t-d}\right)+\varepsilon_{t}, \quad t=1, \ldots, T \\
& \Theta\left(\theta ; y_{t-d}\right)=1-\exp \left(-\theta y_{t-d}^{2}\right)
\end{aligned}
$$

Here $\varepsilon_{t} \sim \operatorname{iid}\left(0, \sigma^{2}\right), \Theta(0)=0$ and $\lim _{x \rightarrow \pm \infty} \Theta(\mathrm{x})=1$. From here, the exponential STAR (ESTAR) model can be established through using Equation (1) and Equation (2):

$$
\begin{aligned}
& y_{t}=\beta y_{t-1}+\gamma y_{t-1}\left[1-\exp \left(-\theta y_{t-d}^{2}\right)\right]+\varepsilon_{t} \\
& \Delta y_{t}=\phi y_{t-1}+\gamma y_{t-1}\left[1-\exp \left(-\theta y_{t-d}^{2}\right)\right]+\varepsilon_{t}
\end{aligned}
$$

Here $\phi=\beta-1$. If $\theta>0$ then equation (4) effectively determines the average inversion speed. The null hypothesis of the KSS test is that the series is not stationary.

In KSS method, in which period the series is stationary is analyzed via the charts. In this context, firstly test statistics are obtained $^{1}$ then these values are normalized by using critical values ${ }^{2}$ and in the last stage, they are transferred to the graphics environment. When deciding on this test, the null hypothesis is rejected when the Calculated Test Statistics is higher than the Critical Value. To perform normalization in this test, both sides of the inequality shown as Calculated Test Statistics> Critical Value is divided into Critical Value. Thus, when the new test statistic is greater than 1, in other words, when the chart located above $y=1$, the null hypothesis is rejected and it is determined that the series are stationary.

In this method, when calculating the test statistics, at the beginning a window is created by taking a certain number of observations (60 in this study) and then a test statistic is calculated for this group. Then each time one observation is left from the beginning, a new observation is added to end, and the window (60-period period) moves along the time frame and thus test statistics are generated for the subsequent periods. Due to this operating mechanism, the test is also called Unit Root Test in Floating Windows oolling Window Unit Root Test. Since it uses different test statistics for the subsequent periods, this method also called as time-varying unit root test.

KSS unit root test was performed for BITCOIN series and the results are presented in Chart 1

\section{Chart 1: KSS Unit Root Test Chart for BITCOIN Series}

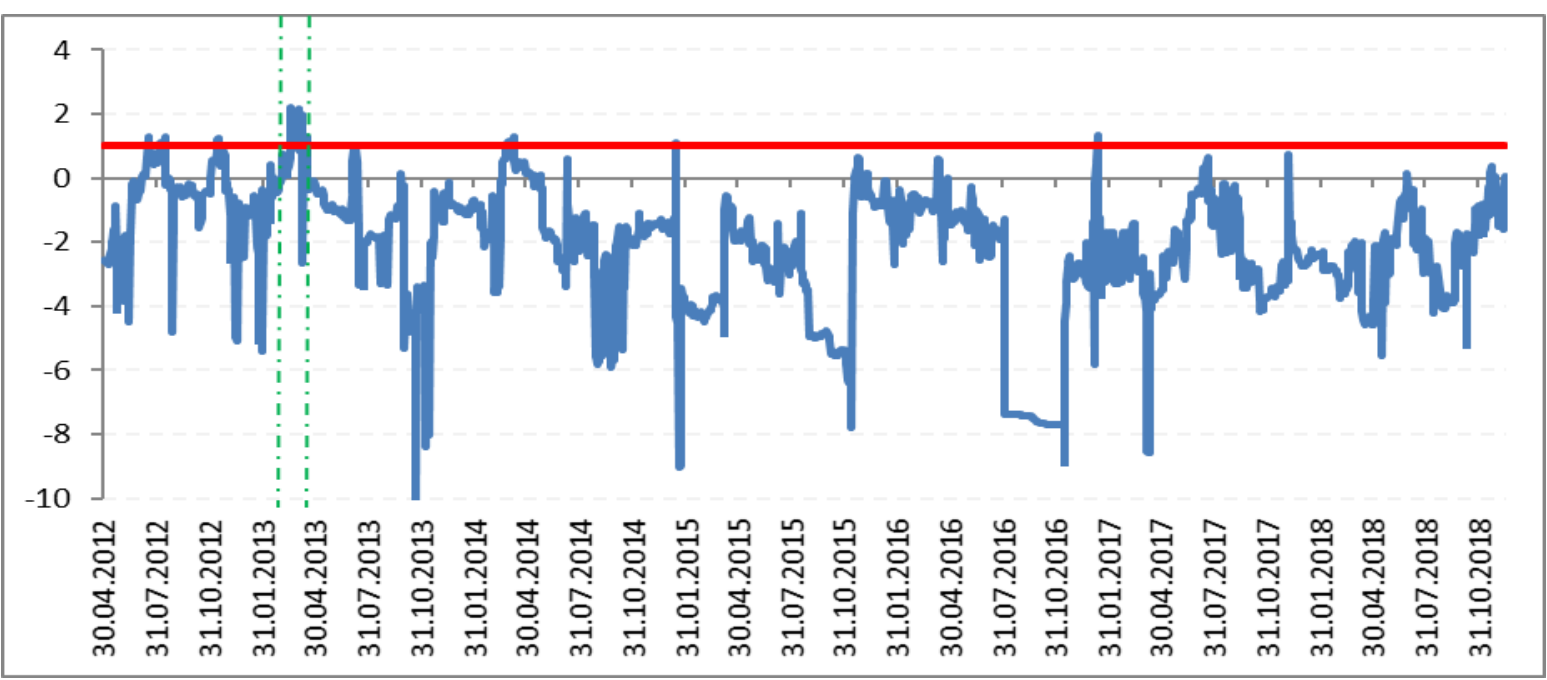

\footnotetext{
1 Test statistics are produced with a 1000 iterative bootstrap cycle.

${ }^{2}$ The asymptotic critical value can be obtained from Kapetanios, Shin and Snell (2003: 364) Table 1, Case I.
} 
According to Chart 1, the returns of BITCOIN seem stationary in the first months of 2013 but it is not possible to mention this situation for the other periods. This is important because it shows that BITCOIN prices have not stabilized yet and have significant fluctuations. In order for investors to trust a financial instrument, the continuity and price stability of the financial instrument have great importance. Therefore, it will be exceedingly useful both national and international regulatory and supervisory agencies are engaged and to place the BITCOIN market on a legal and stable environment. The results of the KSS unit root test for the BIST 100 series are shown in Chart 2.

\section{Chart 2: KSS Unit Root Test Chart for BIST 100 Series}

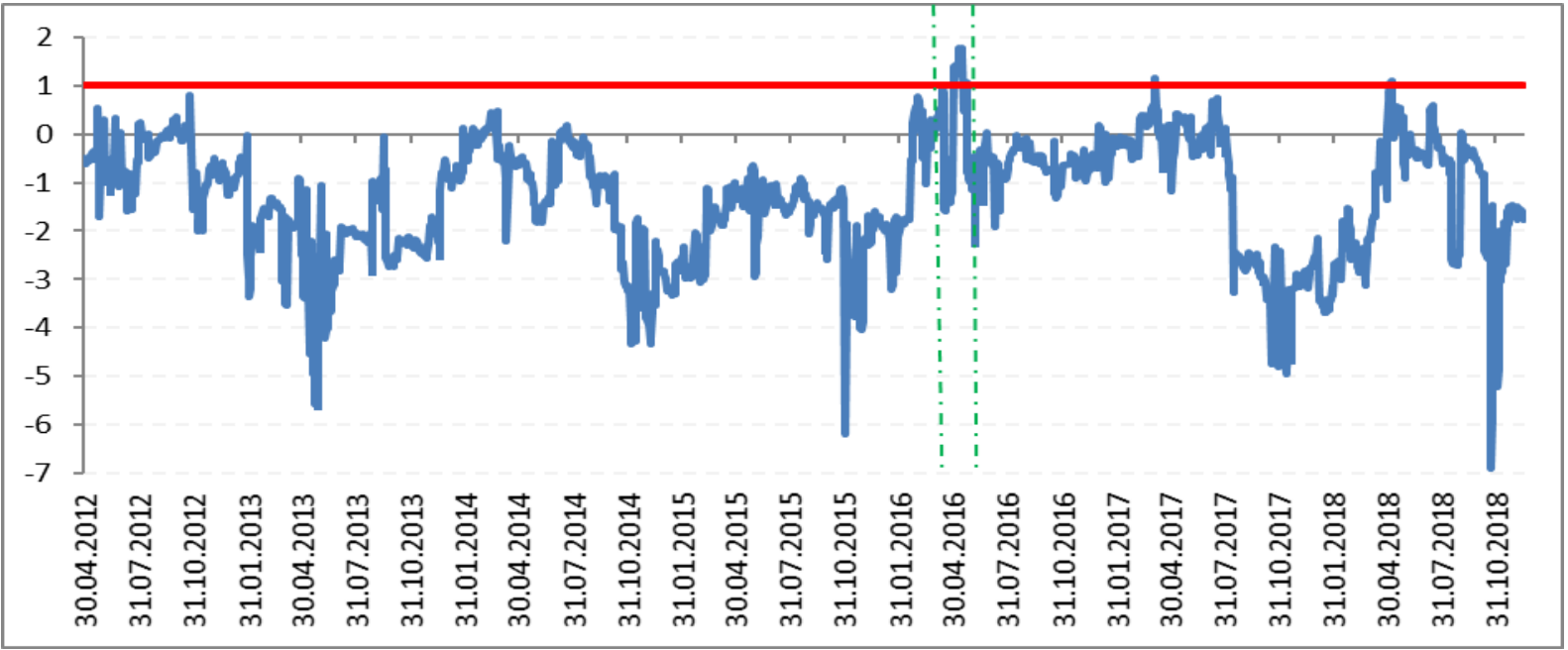

According to Chart 2, the return of BIST 100 is stable in the middle of 2016, while it is not stationary in other periods. This shows that Turkey's stock exchange has a quite fluctuating structure. This result keeps investors away from the stock market and limits increase of financial markets in terms of depth and diversity in Turkey. Therefore, Borsa İstanbul, publicly traded companies (listed companies) and regulatory authorities should give particular importance to ensuring stability in Borsa Istanbul. One of the most important reasons for this volatility is the share of foreign investors in Borsa Istanbul up to 74\%. Foreign investors operating in Borsa Istanbul can quickly leave the stock exchange or move their assets to Borsa istanbul in response to domestic or international changes and developments. This causes significant fluctuations in the returns of stocks traded in Borsa Istanbul. At this point it may be useful to install a Tobin Tax type ${ }^{3}$ braking system.

The results of the KSS unit root test for Gold series are given in Chart 3.

\section{Chart 3: KSS Unit Root Test Chart for Gold Series}

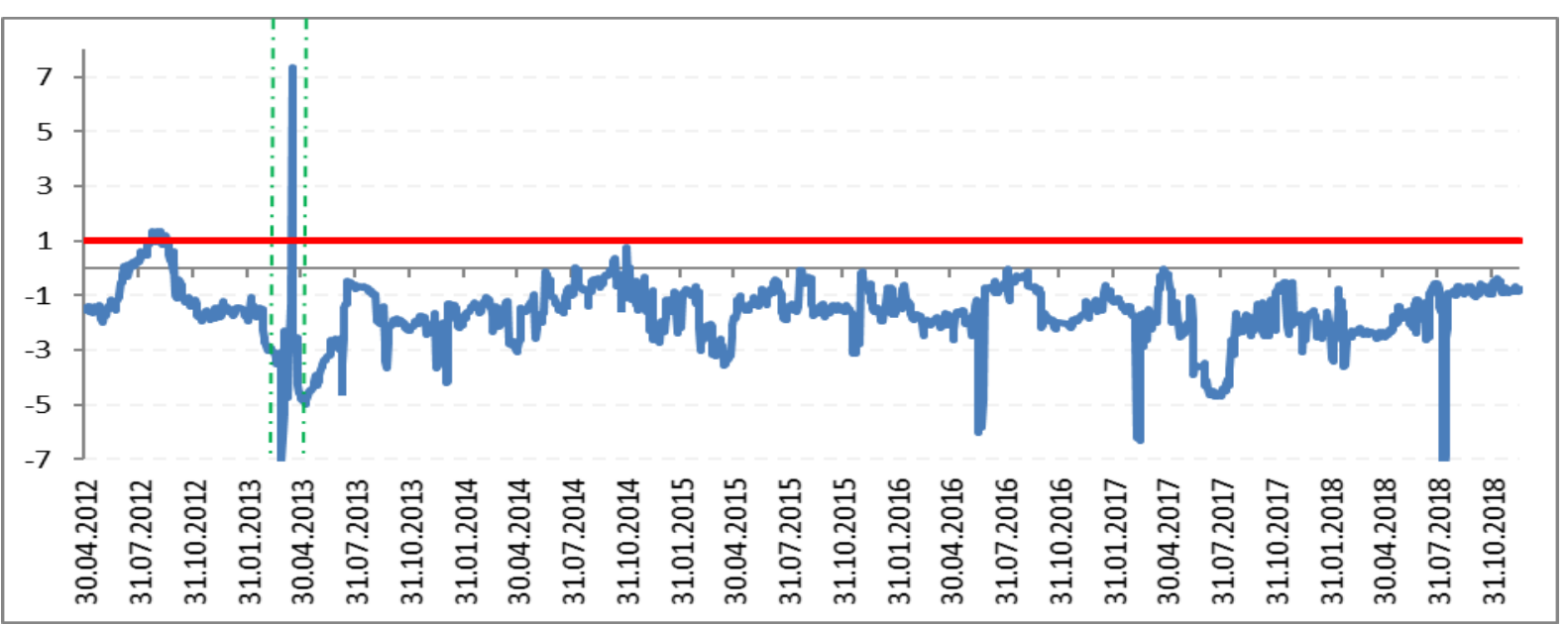

\footnotetext{
${ }^{3}$ Tobin Tax is a type of tax that is expected to be applied to foreign exchange transactions in order to prevent the economic and financial fluctuations caused by the speculative capital flows developed by James Tobin won the Nobel Prize for Economics (Ay and Mangır, 2007).
} 
According to Chart 3, the return of gold series was observed as stable in March 2013 but not in other periods. This finding shows that Gold prices have a highly volatile nature in Turkey. However, gold is considered the most stable investment tool by Turkish society. The reason for this volatility in gold returns is that the price of gold in countries like Turkey is both affected by the increase in USD currency rate and the rise in world gold prices. Especially in the period when economic and political risks increase in the country, the demand for Gold in Turkish society is increasing, which in turn causes fluctuations in the yield of Gold. Chart 3 shows significant fluctuations in gold returns during the period of the coup attempt dated July 15, 2016, in the referendum period of 16 April 2017 and in the period of August 14, 2018 when the dollar tested the upper limit of $7 \mathrm{TL}$. The management of Istanbul Gold Exchange which was established on July 26, 1995 (Borsa İstanbul, 2018) in order to ensure stability in gold prices and to bring the gold held by the household as under-the-mattress savings to the economy has an important key role for this purpose.

The results of the KSS unit root test for the USD series are presented in Chart 4.

\section{Chart 4: KSS Unit Root Test Chart for Usd Series}

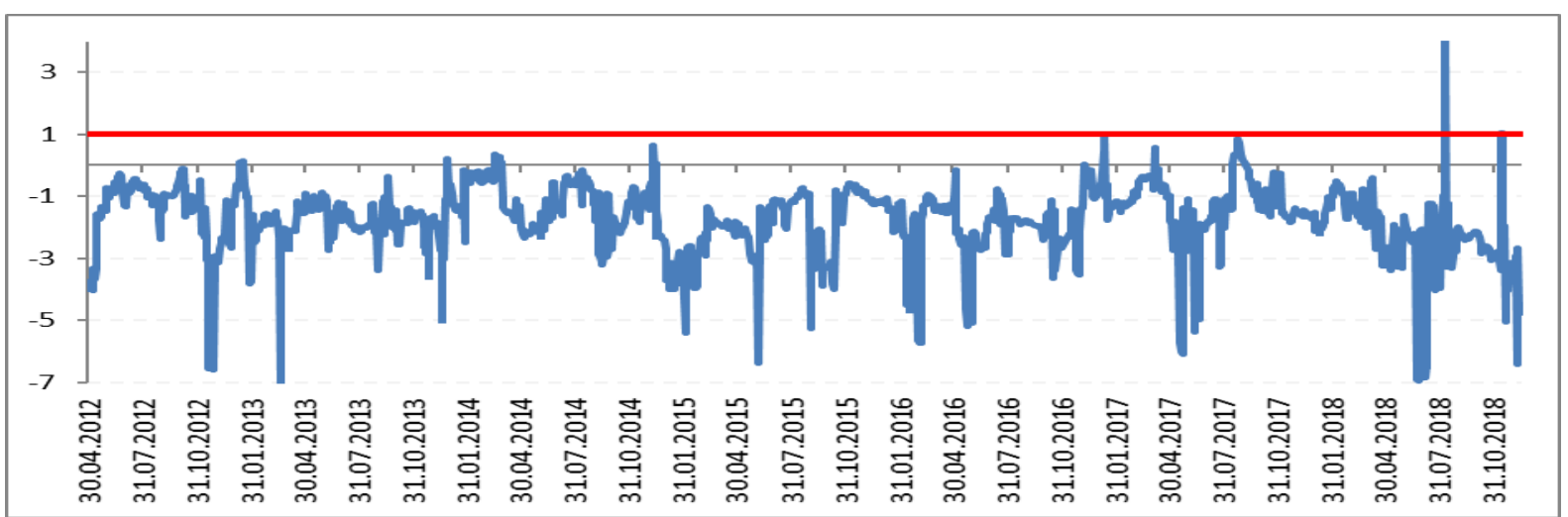

According to Chart 4, the USD returns showed an abnormal fluctuation in August 2018, when the Dollar tested above 7 TL. Afterward, it was stable for a short-term but during the next periods, it continued to fluctuate. Based on this result, it can be said that USD currency and its demand has a volatile structure in Turkey. Turkey is one of the countries with high USD demand stemming from some reasons such as performing a large part of foreign trade volume via the USD currency, the vast majority of external debt is based on USD currency, and dollarization activities which is triggered by economic actor's confidence feelings related to USD currency. Rest on this observation, it is useful to take the necessary measures in this field and try to make the USD rate more stable. It may be stated that the CB of Turkey successfully managed the Dollar crisis in August 2018. However, it is beneficial for managers to continue to be sensitive about this issue. One of the most important factors lie behind on this instability of Usd currency rate is the since May 2013, a gradual decrease of the expansionary monetary policies implemented by the US Federal Reserve (FED) after the 2008 global economic crisis. And since October 2014, the Fed has been applying tightening monetary policy and it has been increasing interest rate levels gradually.

The results of the KSS unit root test for the EURO series are given in chart 5.

\section{Chart 5: KSS Unit Root Test Chart for Euro Series}

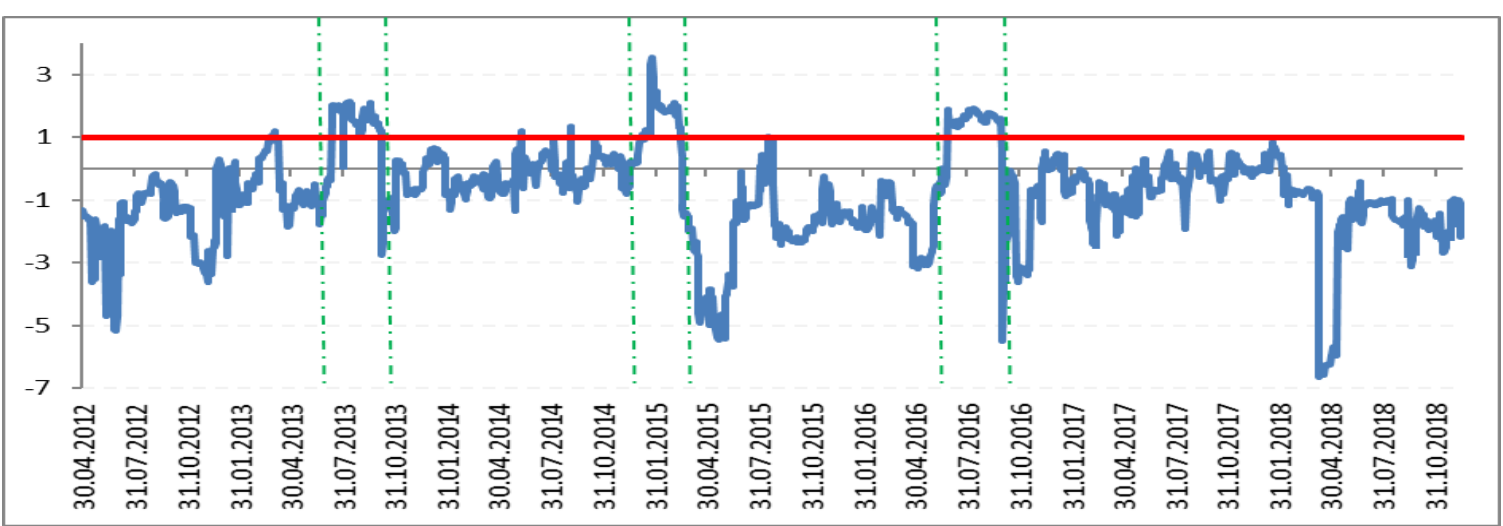


According to Chart 5, the return of the Euro is more stable than the Dollar. In the third quarter of 2013, in the first quarter of 2015 and in the third quarter of 2016, the return of the Euro was stable. Starting from this chart, for investors in Turkey instead of investment in USD currency it can be stated that preferring Euro investment may be more logical and reasonable. It may also be useful for economic administration to convert reserve assets and foreign debts of the country into Euro instead of Usd. Similarly, private companies may also convert their Usd debt to Euro through the swap transactions. The results of the KSS unit root test for TAHVIL series are given in Chart 6.

\section{Chart 6: KSS Unit Root Test Chart for Bond Series}

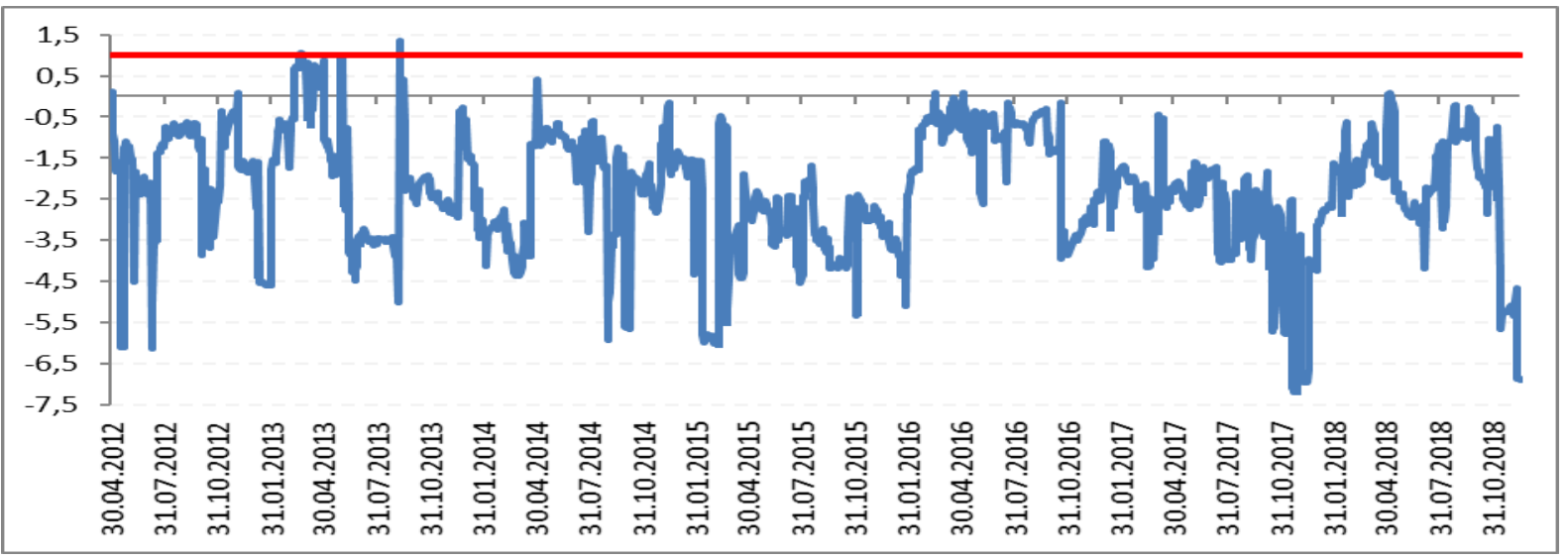

According to chart 6, the yields of government bonds in Turkey in mid-2013 became partly stationary (stable), it has fluctuated in general. Therefore, the demand of individual investors, firms and foreign investors to Turkish Government Bonds is adversely affected. It is very useful for policy makers to take measures to ensure financial stability in the country.

\subsection{Causality Test}

Linear causality tests can test the presence or absence of a single causal relationship valid for the whole time period. However, the causality relations between the series can change over time due to the structural changes experienced due to economic and social developments (Tang and Jang, 2009). While there is no causality relationship between two series in a certain period, causality relationship can be seen in the sub-sample dimensions. (Balcılar vd. 2016). This stability of causality relationship can be tested by using time-varying causality analysis. In this study, the existence of causality relations between series analyzed via the time-varying and non-linear LBGC causality test developed by Liv et al. (2016). In this test, it is also taken into consideration that the causality relations between the series can vary over time and the series may not be linear. The null hypothesis of the LBGC test is that there is no causality relationship between the series.

This test consists of the combination of Hacker and Hatemi-J (2006) test, Hatemi-J (2012) test, Kapetanios, Shin and Snell (2003) test. This method is superior to other tests in that it can reveal the causal relationships that exist in some periods of the analysis period. Hatemi-J (2012) proposes a new method for the accurate determination of the lag length: He names this method as Khatami-J Criterion (HJC) which is the combination of Schwarz and Hannan-Quin methods and calculates as follows:

$$
H J C=\operatorname{Ln}\left(\operatorname{det} \widehat{\Omega}_{j}\right)+j\left(\frac{n^{2} \operatorname{Ln} T+2 n^{2} \operatorname{Ln}(\operatorname{LnT})}{2 T}\right), j=0, \ldots, p
$$

In the formula $\widehat{\Omega}_{j}$; is the maximum probability estimate of the covariance matrix of the VAR model with the number of delays. $T$ shows the time dimension.

In the LBGC method, in which periods there is a causality relationship between the series is analyzed through the charts. In this context, firstly test statistics are obtained, then these values are normalized by using critical value and in the last stage, they are transferred to the chart environment. When deciding on this test, the null hypothesis is rejected when the Calculated Test Statistics is higher than the Critical Value. To perform normalization in this test, both sides of the inequality shown as Calculated Test Statistics> Critical Value is divided into Critical Value. Thus, when the new test statistic is greater than 1 , in other words, when the chart located above $y=1$, the null hypothesis is rejected and it is determined that there is causality relation from series 1 to 2 . 
In this method, when calculating the test statistics, at the beginning a window is created by taking a certain number of observations (60 in this study) and then a test statistic is calculated for this group. Then each time one observation is left from the beginning, a new observation is added to end, and the window (60-period period) moves along the time frame and thus test statistics are generated for the subsequent periods. Due to this operating mechanism, the test is also called causality relation Test in Floating Windows or Rolling Window causality relation. Since it uses different test statistics for the subsequent periods, this method also called as time-varying causality test (Yllancl and Bozoklu, 2014:215).

In this study, the LBHC causality test from BITCOIN series to BIST 100 series was performed and the results are presented in Chart 7.

\section{Chart 7: Causality Relationship from The Bitcoin to BIST 100}

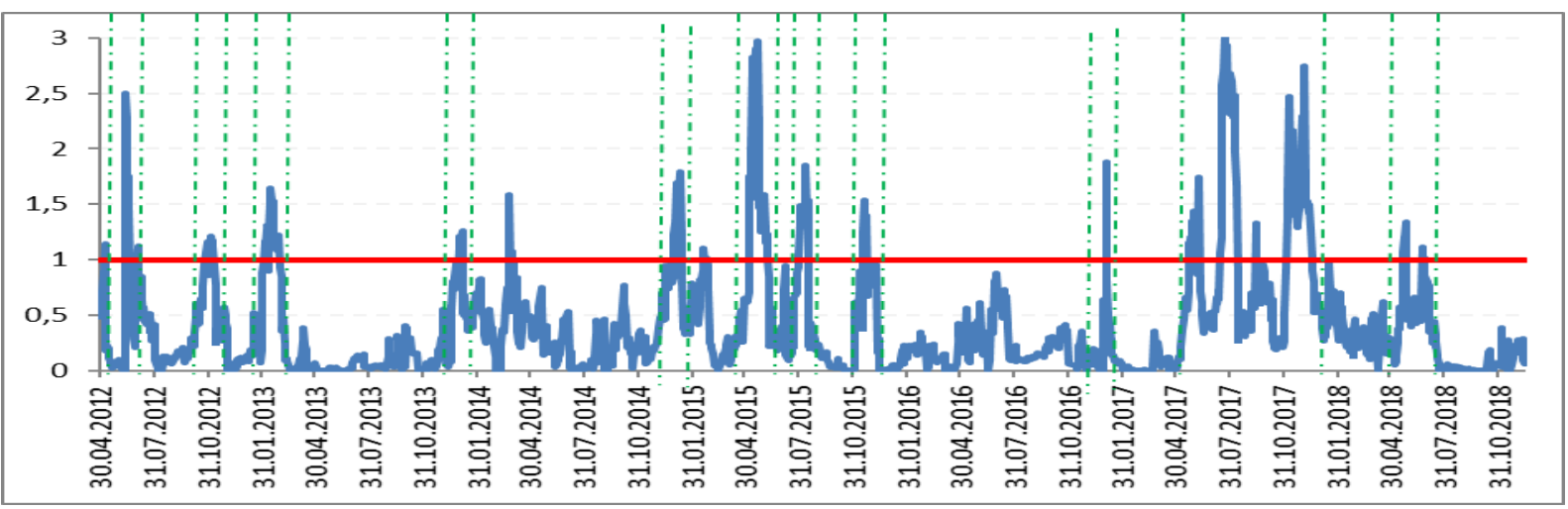

According to Chart 7, from Bitcoin's return to Bist 100 return, there is causality relationship in June 2012, OctoberNovember 2012, February 2013, January 2014, January 2015, May-June 2015, August 20152, November 2015, May-June 2017, July-August 2017, November-December 2017 and May 2018. Based on this finding, it may be stated that there is a significant causal relationship between Bitcoin's return and Borsa İstanbul's return. This shows that Bitcoin is becoming an alternative (substitute) investment tool for domestic and foreign investors compared to Borsa Istanbul. Therefore investors take into account the Bitcoin and other sub-coins along with the stocks. It is time to mention that both Borsa istanbul management and macro economy policymakers should take the Crypto Coins more seriously and prepare a legal basis for it. In the causality relationship between Bitcoin and the BIST 100 in 2017, the increase in Bitcoin prices in the related period is considered to be effective. Changes in bitcoin prices can be viewed through the Chart 8 as follows:

\section{Chart 8: Change in Bitcoin Prices}

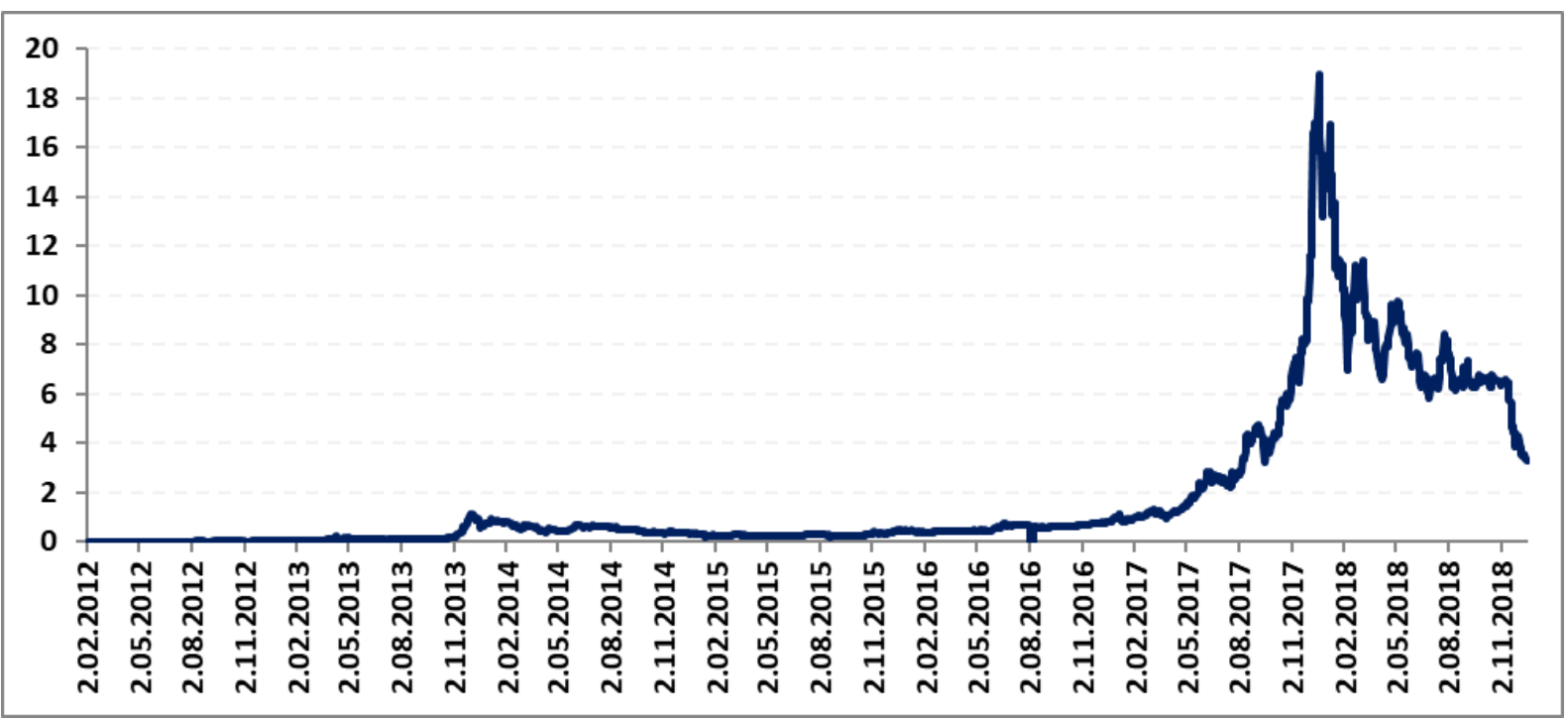

The results of the LBHC causality test from the return of Bitcoin to the return of Gold are presented in Chart 9. 


\section{Chart 9: Causality Relationship From Bitcoin to the Gold}

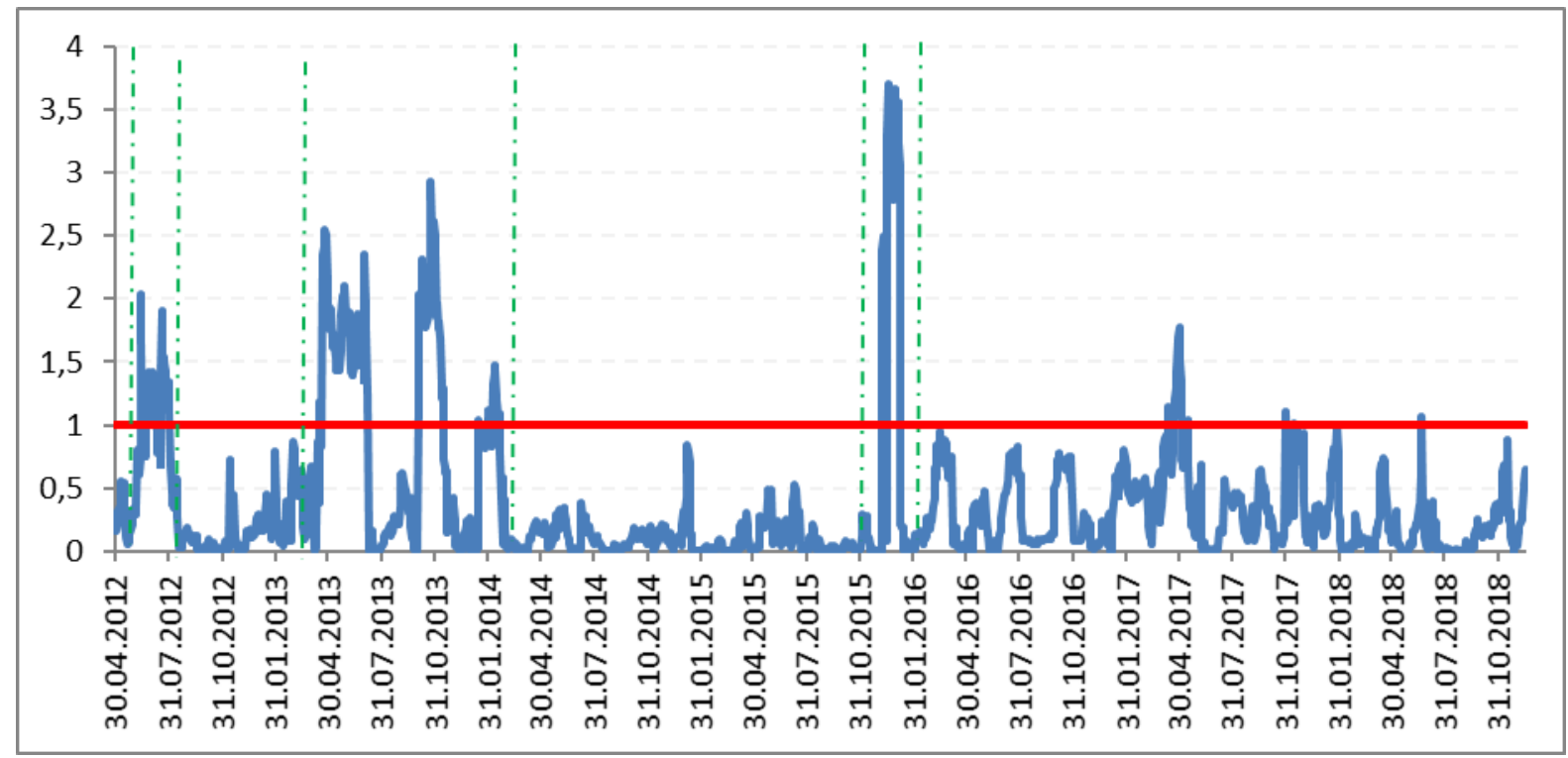

According to Chart 9, there is a causality relationship from the return of Bitcoin to the return of Gold in June-July 2012, April-July 2013, October-November 2013, January-February 2014, December 2015-January 2016 and April 2017. What is interesting here is that in 2017 when Bitcoin prices increased by 19 times, there was no causality relation between Bitcoin and the gold. This shows that Bitcoin is preferred by investors who prefer to take more risks, while gold is preferred by investors who want robust and stable investment instruments. Causality from Bitcoin towards to Gold was observed in less frequency than from Bitcoin to Bist 100 during the analysis period. This situation shows that Bitcoin has more substitute relationship with Bist 100 when compared to Gold.

The results of the LBHC causality test from the return of Bitcoin to the return of USD are given in Chart 10.

\section{Chart 10: Causality Relationship From Bitcoin to the USD}

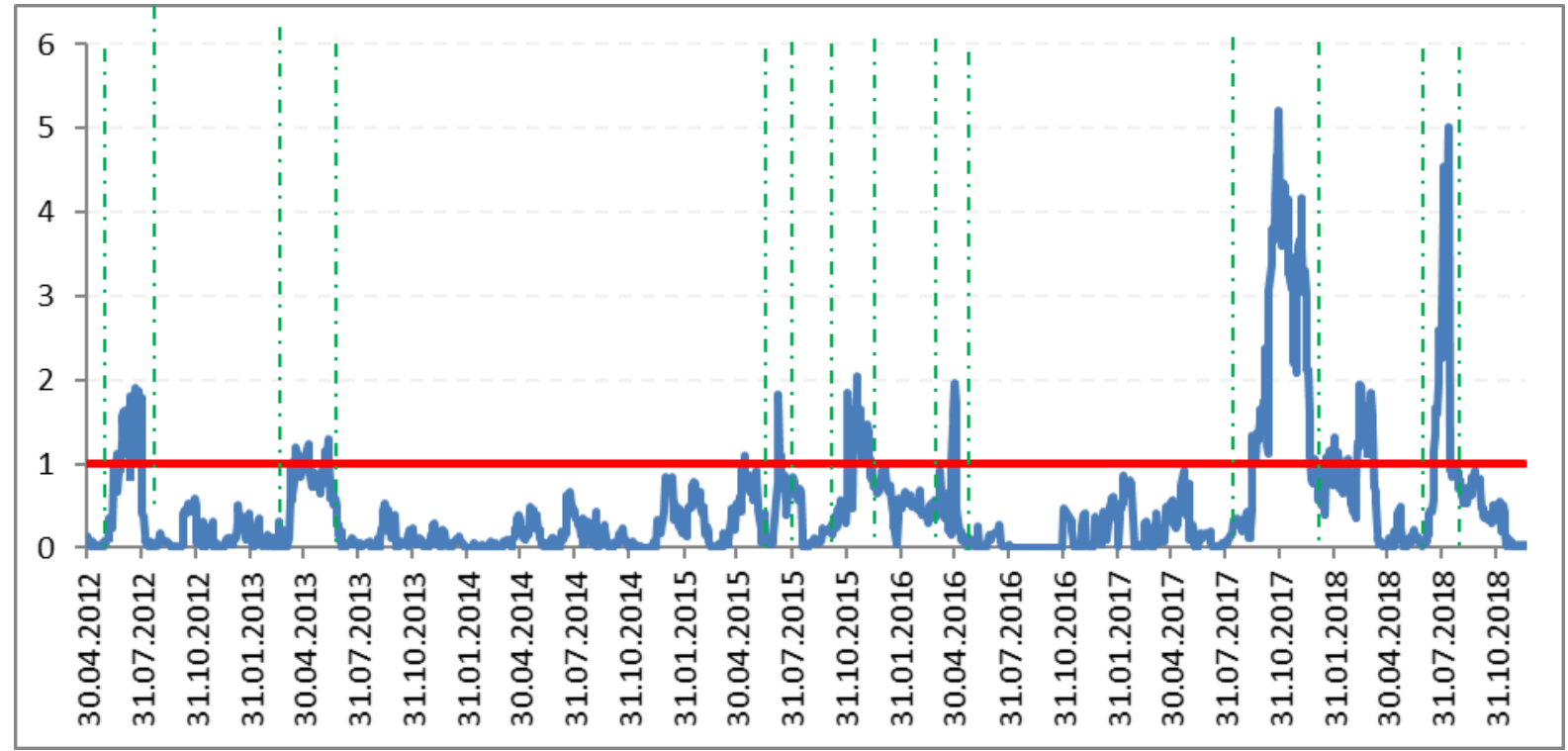

According to Chart 10, there is a causal relationship between the return of Bitcoin and the return of the Usd in limited periods. When it is analyzed by the terms, causality relationship is seen in June - July 2012, April-May 2013, June 2013, July 2015, November-December 2015, April-May 2016, September-December 2017, January-February 2018, March 2018 and July 2018. The causality relationship which is seen in the second half of 2017 when Bitcoin prices increased rapidly and in 
the first half of 2018 when Bitcoin falls off rapidly show that Bitcoin and Usd are beginning to substitute investment tools to each other in Turkey case.

The results of the LBHC causality test from the return of BITCOIN to the return of the EURO are given in Chart 11.

\section{Chart 11: Causality Relationship from Bitcoin to the Euro}

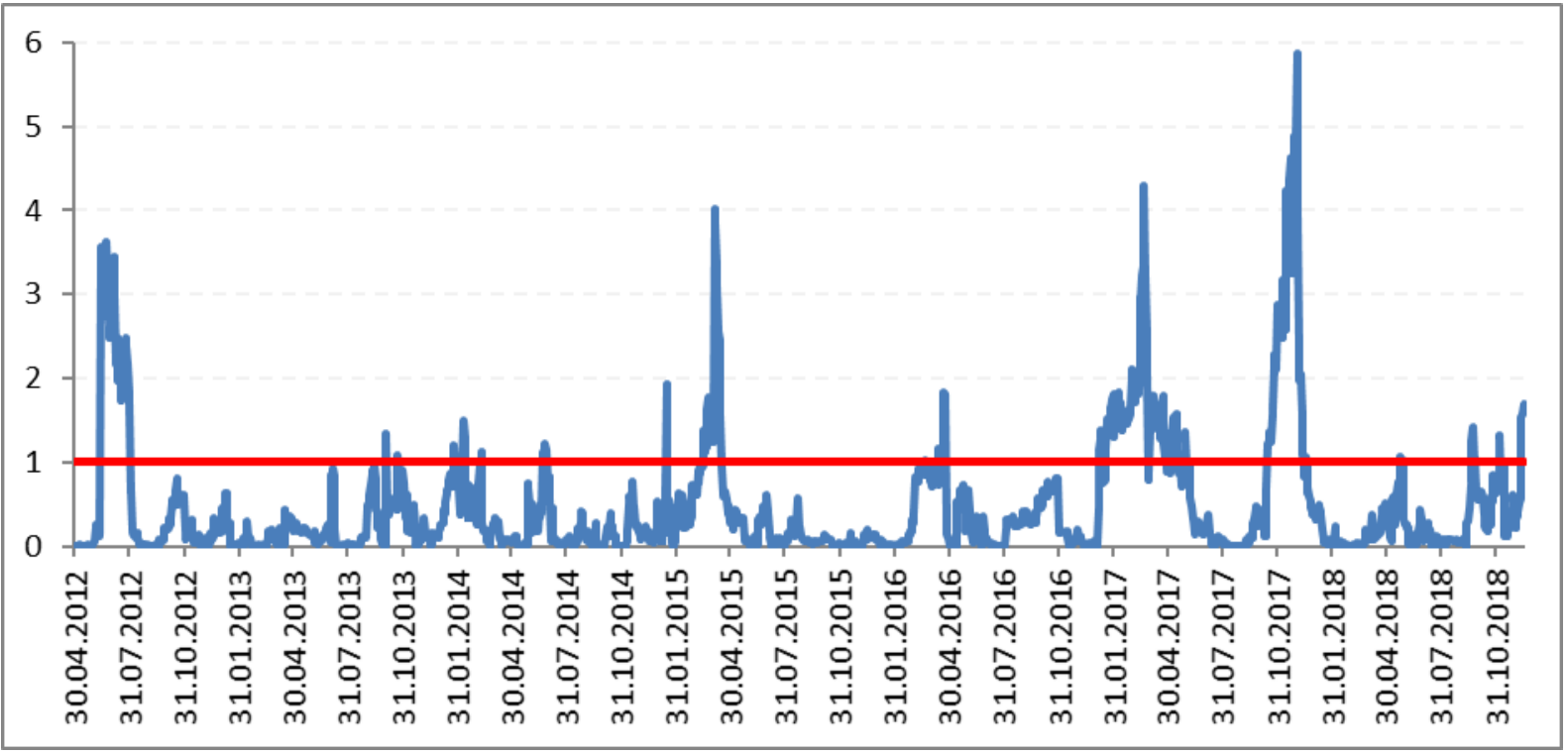

According to the results of Graph 11, the causality relation between the return of Bitcoin and the return of the Euro is similar to the causality relationship between the return of Bitcoin and the return of the Dollar. Chart 10 shows that the causality relation between Bitcoin and Euro is seen in June-July 2012, February 2014, June 2014, March-April 2015, April 2016, January-June 2017, October-December 2017, September-December 2018. The causality relationship which is seen in the second half of 2017 when Bitcoin prices increased rapidly shows that Bitcoin and Euro like Usd are beginning to substitute investment tools to each other in Turkey case.

The results of the LBHC causality test from the return of Bitcoin to the return of Bonds are given in Chart 12.

\section{Chart 12: Causality Relationship From Bitcoin to the Bond}

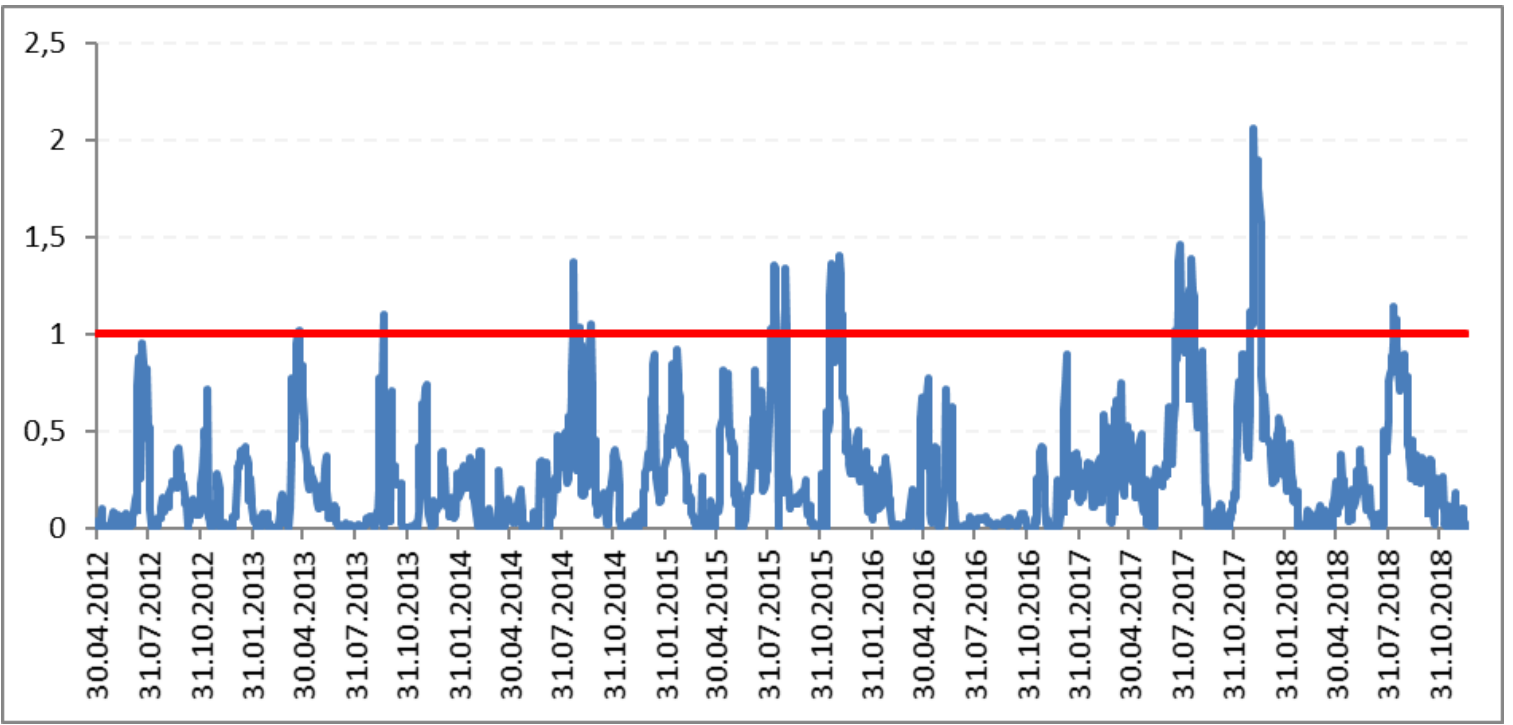

According to Chart 12, there is a relatively less causality relationship between the Bitcoin and Bond. In this case, it can be said that Bitcoin is not a substitute for the bond. In terms of sub-periods, there is a causal relationship from Bitcoin towards 
to Bond in August 2014, August 2015, November-December 2015, July-August 2017, December 2017 and August 2018. The remarkable point in this analysis is that the causality relationship from Bitcoin towards Bond in the period when Bitcoin and Usd prices are intensively increasing. In other words, when investors decide between Bonds and Bitcoin, they took into consideration the Usd prices as well as Bitcoin prices.

\section{CONCLUSION AND RECOMMENDATIONS}

In this study, in Turkey interactions among the crypto-currencies (Bitcoin), stocks (Bist 100), foreign exchange, bonds and gold has been analyzed during the 02.02.2012-17.12.2018 period by using time-varying analysis. In the study, the stationarity of the series was examined through KSS method developed by Kapetanios, Shin and Snell (2003) with timevarying nonlinear unit root test.

In this test, Bitcoin's return series was stationary in the first months of 2013 but was not stationary in the following periods. This is important because it shows that Bitcoin prices have not yet stabilized worldwide and still contain significant fluctuations. The continuity and stability of the financial instrument is crucial for investors to trust a financial instrument. Therefore, it will be exceedingly useful both national and international regulatory and supervisory agencies are engaged and to place the BITCOIN market on a legal and stable environment. In the KSS unit root test conducted for the return of BIST100, it is observed that BIST 100 returns were found to be stable in the middle of 2016 but not stable in the following periods. This shows that Turkey's stock exchange has a quite fluctuating structure. This result keeps investors away from the stock market and limits increase of financial markets in terms of depth and diversity in Turkey. Therefore, Borsa İstanbul, publicly traded companies (listed companies) and regulatory authorities should give particular importance to ensuring stability in Borsa Istanbul. One of the most important reasons for this volatility is the share of foreign investors in Borsa Istanbul up to $74 \%$. Foreign investors operating in Borsa Istanbul can quickly leave the stock exchange or move their assets to Borsa İstanbul in response to domestic or international changes and developments. This causes significant fluctuations in the returns of stocks traded in Borsa Istanbul. At this point it may be useful to install a Tobin Tax type braking system.

The return of gold series was observed as stable in March 2013 but not in other periods. This finding shows that Gold prices have a highly volatile nature in Turkey. However, gold is considered the most stable investment tool by Turkish society. The reason for this volatility in gold returns is that the price of gold in countries like Turkey is both affected by the increase in USD currency rate and the rise in world gold prices. Especially in the period when economic and political risks increase in the country, the demand for Gold in Turkish society is increasing, which in turn causes fluctuations in the yield of Gold. Chart 3 shows significant fluctuations in gold returns during the period of the coup attempt dated July 15, 2016, in the referendum period of 16 April 2017 and in the period of August 14, 2018 when the dollar tested the upper limit of 7 TL. The management of Istanbul Gold Exchange which was established on July 26, 1995 (Borsa İstanbul, 2018) in order to ensure stability in gold prices and to bring the gold held by the household as under-the-mattress savings to the economy has an important key role for this purpose.

The USD returns showed an abnormal fluctuation in August 2018, when the Dollar tested above 7 TL. Afterward, it was stable for a short-term but during the next periods, it continued to fluctuate. Based on this result, it can be said that USD currency and its demand has a volatile structure in Turkey. Turkey is one of the countries with high USD demand stemming from some reasons such as performing a large part of foreign trade volume via the USD currency, the vast majority of external debt is based on USD currency, and dollarization activities which is triggered by economic actor's confidence feelings related to USD currency. Rest on this observation, it is useful to take the necessary measures in this field and try to make the USD rate more stable. It may be stated that the CB of Turkey successfully managed the Dollar crisis in August 2018. However, it is beneficial for managers to continue to be sensitive about this issue. One of the most important factors lie behind on this instability of Usd currency rate is the since May 2013, a gradual decrease of the expansionary monetary policies implemented by the US Federal Reserve (FED) after the 2008 global economic crisis. And since October 2014, the Fed has been applying tightening monetary policy and it has been increasing interest rate levels gradually.

The return of the Euro is more stable than the Dollar. In the third quarter of 2013, in the first quarter of 2015 and in the third quarter of 2016, the return of the Euro was stable. Starting from this chart, for investors in Turkey instead of investment in USD currency it can be stated that preferring Euro investment may be more logical and reasonable. It may also be useful for economic administration to convert reserve assets and foreign debts of the country into Euro instead of Usd. Similarly, private companies may also convert their Usd debt to Euro through the swap transactions. The results of the KSS unit root test for TAHVIL series are given in Chart 6.

The yields of government bonds in Turkey in mid-2013 became partly stationary (stable), it has fluctuated in general. Therefore, the demand of individual investors, firms and foreign investors to Turkish Government Bonds is adversely affected. It is very useful for policy makers to take measures to ensure financial stability in the country. 
In the study, the existence of causality relations between the series was examined through LBGC time-varying nonlinear causality test developed by Li et al (2016). As a result of causality relationship test, it id observed that there is a significant causal relationship from Bitcoin's return to Borsa istanbul's return. This shows that Bitcoin is becoming an alternative (substitute) investment tool for domestic and foreign investors compared to Borsa Istanbul. It is time to mention that both Borsa istanbul management and macro economy policymakers should take the Crypto Coins more seriously and prepare a legal basis for it.

There is a causality relationship from the return of Bitcoin to the return of Gold in June-July 2012, April-July 2013, OctoberNovember 2013, January-February 2014, December 2015-January 2016 and April 2017. What is interesting here is that in 2017 when Bitcoin prices increased by 19 times, there was no causality relation between Bitcoin and the gold. This shows that Bitcoin is preferred by investors who prefer to take more risks, while gold is preferred by investors who want robust and stable investment instruments. Causality from Bitcoin towards to Gold was observed in less frequency than from Bitcoin to Bist 100 during the analysis period. This situation shows that Bitcoin has more substitute relationship with Bist 100 when compared to Gold.

There is a causal relationship between the return of Bitcoin and the return of the Usd in limited periods. When it is analyzed by the terms, causality relationship is seen in June - July 2012, April-May 2013, June 2013, July 2015, November-December 2015, April-May 2016, September-December 2017, January-February 2018, March 2018 and July 2018. The causality relationship which is seen in the second half of 2017 when Bitcoin prices increased rapidly and in the first half of 2018 when Bitcoin falls off rapidly show that Bitcoin and Usd are beginning to substitute investment tools to each other in Turkey case.

The causality relation between the return of Bitcoin and the return of the Euro is similar to the causality relationship between the return of Bitcoin and the return of the Dollar. Chart 10 shows that the causality relation between Bitcoin and Euro is seen in June-July 2012, February 2014, June 2014, March-April 2015, April 2016, January-June 2017, OctoberDecember 2017, September-December 2018. The causality relationship which is seen in the second half of 2017 when Bitcoin prices increased rapidly shows that Bitcoin and Euro like Usd are beginning to substitute investment tools to each other in Turkey case.

There is a relatively less causality relationship between the Bitcoin and Bond. In this case, it can be said that Bitcoin is not a substitute for the bond. In terms of sub-periods, there is a causal relationship from Bitcoin towards to Bond in August 2014, August 2015, November-December 2015, July-August 2017, December 2017 and August 2018. The remarkable point in this analysis is that the causality relationship from Bitcoin towards Bond in the period when Bitcoin and Usd prices are intensively increasing. In other words, when investors decide between Bonds and Bitcoin, they took into consideration the Usd prices as well as Bitcoin prices.

\section{CONCLUSION}

Based on the findings obtained in this study, it may be accepted that Bitcoin has been becoming an alternative investment/savings tool for the Turkey case. Therefore, it can be said that it is time for the economy administration and banks to prepare the necessary legal framework in this field. In order for the crypto coins to become widespread and to stabilize, their validity / recognition in official and private transactions should be increased. It should be noted that Bitcoin has a great potential to prevent of tax evasion, to terminate the informal economy and eliminate intermediation costs. In this subject, Turkey as a country can take a benefit from the experience of Japan and China.

\section{REFERENCES}

Ağazadebin, S. (2014). Doğrusal Olmayan Birim Kök Testleriyle Rusya için Satın Alma Gücü Paritesi Hipotezinin İncelenmesi. The Journal of Anadolu University Social Sciences, 14(4), 15-24.

Ateş, A., B. (2016). Kripto Para Birimleri, Bitcoin ve Muhasebesi, The Journal of Çankırı University Social Sciences Institution, 7(1), p.349366.

Atik M., Köse Y., Yılmaz B., Sağlam F., (2015). Kripto Para: Bitcoin ve Döviz Kurları Üzerine Etkileri, The Journal of Bartın University School of Economics and Administrative Science, 6 (11), 247-261.

Ay, A. ve Mangır, F. (2007). Uluslararası Finansal Entegrasyon Bağlamında Sermayenin Vergilendirilmesi: Tobin Vergisi. Maliye Dergisi, 153, 123-141.

Balcilar, M., Chang,T., Gupta,R. and Li, X. (2016). The Causal Relationship Between Economic Policy Uncertainty and Stock Returns In China and India: Evidence From A Bootstrap Rolling-Window Approach. Emerging Markets Finance \& Trade, 52, 674-689.

Borsa istanbul (2018). Kıymetli Madenler ve Kıymetli Taşlar Piyasası. http://www.borsaistanbul.com/urunler-vepiyasalar/piyasalar/kiymetli-madenler-ve-kiymetli-taslar-piyasasi, (Accessed in 23.12.2018). 
Çarkacıoğlu, A. (2016). Kripto -Para Bitcoin, Capital Markets Board Research Paper, p. 1-84

Destek, M. A. (2016). Satın Alma Gücü Paritesi Hipotezi Geçerliliğinin Fourier Birim Kök Testleri ile İncelenmesi: OECD Ülkeleri Örneği. Gaziantep University Journal of Social Sciences, 15(1), 73-87.

Gültekin, Y., Bulut, Y. (2016). Bitcoin Ekonomisi: Bitcoin Eko-Sisteminden Doğan Yeni Sektörler ve Analizi, Adnan Menderes University, The Journal of Social Sciences Institution, 3(3), p.82-92

Hacker, R. S. and Hatemi-J, A. (2006).Tests for Causality between Integrated Variables Using Asymptotic and Bootstrap Distributions: Theory and Application. Applied Economics, 38, 1489-1500.

Hatemi-J, A. (2012). Asymmetric Causality Tests with an Application. Empirical Economics, 43(1), 447-456.

Hepkorucu A., Genç, S., (2017). Finansal Varlık Olarak Bitcoin'in İncelenmesi ve Birim Kök Yapısı Üzerine Bir Uygulama, Osmaniye Korkut Ata Üniversitesi İktisadi ve İdari Bilimler Fakültesi Dergisi, 1(2), 47-58.

Kapetanios, G., Shin, Y. and Snell, A. (2003). Testing for a Unit Root in the Nonlinear STAR Framewor. Journal of Economics, 112(2), 359-379.

Li, X., Balcılar, M., Gupta, M. and Chang, T. (2016). The Causal Relationship Between Economic Policy Uncertainty and Stock Returns in China and India: Evidence A Bootstrap Rolling-Window Approach. Emerging Markets Finance and 674-689.

Tang, C. and Jang, S. (2009). The Tourism-Economy Causality in the Uni ted States: A Sub-Industry Level Examination. Tourism Management, 30, 553-8.

Yılancı, V. (2009). Fisher Hipotezinin Türkiye İçin Sınanması: Doğrusal Olmayan Eşbütünleşme Analizi. Atatürk Üniversitesi İktisadi ve İdari Bilimler Dergisi, 23(4), 205-213.

Yılancı, V. Bozoklu, S. (2014). Price and Trade Volume Relationship in Turkish Stock Market: A Time-Varying Asymmetric Causality Analysis. Ege Academic Review, 14(2), 211-220. 